\title{
Diabetic Foot: Epidemiological, Therapeutic and Evolutionary Aspects in the Department of Medicine and Endocrinology of the Hospital in Mali, Mali
} \author{
Assa Traore $^{9}$ \\ ${ }^{1}$ Department of Medicine of the Mali Hospital, Bamako, Mali \\ ${ }^{2}$ National Center for Scientific and Technological Research (CNRST), Bamako, Mali \\ ${ }^{3}$ Kati Reference Center, Kati, Mali \\ ${ }^{4}$ Gynaecology Department of the Mali Hospital, Bamako, Mali \\ ${ }^{5}$ Department of Medicine and Medical Specialty of the Fousseyni Daou Hospital, Kayes, Mali \\ ${ }^{6}$ Nephrology Unit of the Fousseyni DAOU Hospital, Kayes, Mali \\ ${ }^{7}$ Health and Social Affairs Department of the National Police, Bamako, Mali \\ ${ }^{8}$ Internal Medicine Department of the Gabriel Toure University Hospital, Bamako, Mali \\ ${ }^{9}$ Faculty of Medicine, Bamako, Mali \\ ${ }^{10}$ Internal Medicine Service of the Point G University Hospital, Bamako, Mali \\ Email: ${ }^{\star}$ docteurdoumbia@gmail.com
}

Nanko Doumbia ${ }^{1,2}$, Adama Alexis Diarra3 ${ }^{3}$, Seydou Mariko 2,4, Drissa Sangare, 2,5, Danfaga Bakary3, Nouhoum Ouologuem1,2, Samaké Magara',6, Sekou Mamadou Cisse5, Mamady Coulibaly2,7, Mahamadou Saliou 2,8, Bakary Dembele², Yacouba L. Diallo1,2, Amadou Kone1, Modibo Mariko1, Bah Traore1, Massama Konate ${ }^{1,9}$, Djenebou Traore ${ }^{9,10}$, Djeneba Sylla, ${ }^{1,9}$, Kaya Assetou Soucko, ${ }^{9,10}$,

How to cite this paper: Doumbia, N., Diarra, A.A., Mariko, S., Sangare, D., Bakary, D., Ouologuem, N., Magara, S., Cisse, S.M., Coulibaly, M., Saliou, M., Dembele, B., Diallo, Y.L., Kone, A., Mariko, M., Traore, B., Konate, M., Traore, D., Sylla, D., Soucko, K.A. and Traore, A. (2022) Diabetic Foot: Epidemiological, Therapeutic and Evolutionary Aspects in the Department of Medicine and Endocrinology of the Hospital in Mali, Mali. Journal of Diabetes Mellitus, 12, 18-27.

https://doi.org/10.4236/jdm.2022.121003

Received: October 10, 2021

Accepted: December 14, 2021

Published: December 17, 2021

\begin{abstract}
Introduction: The diabetic foot remains a public health problem due to its high frequency, difficult and costly management. The aim of this study was to determine the epidemiological, therapeutic and evolutionary aspects of the diabetic foot in a hospital setting in Bamako. Methodology: This is a retrospective, descriptive, cross-sectional and monocentric study conducted between September 1, 2011 and December 31, 2015 on diabetic patients aged 14 years and older arriving in our department with a foot infection. Results: We identified 94 cases of diabetic foot infection out of a total of 828 hospitalized patients, a prevalence of $11.35 \%$. The age range $41-60$ years represented 57 cases $(60.6 \%)$, the extreme ages were 14 and 81 years. Men (38.3\%), women (61.7\%) with a sex ratio of $0.62 \%$. Housewives $50 \%$, illiterate 51 cases $(54.3 \%)$, low economic standard of living 40 cases (42.6\%), presence of osteitis 40 cases (42.6\%), foot at stage D Grade3 28 cases (29.8\%). Management was medical in 48 cases $(51.1 \%)$, treatment with insulin 58 cases (61.7\%), Amoxicillin +
\end{abstract}


Copyright $\odot 2022$ by author(s) and Scientific Research Publishing Inc. This work is licensed under the Creative Commons Attribution International License (CC BY 4.0).

http://creativecommons.org/licenses/by/4.0/

\section{Open Access}

Metronidazole used 36 cases (38.29\%). Amputation was performed in 35 cases (37.2\%). Deaths concerned 5 patients (9.6\%) with hypoglycemia as the main cause in 4 cases. Conclusion: Diabetic foot is a frequent complication of diabetes. The establishment of a multidisciplinary team should contribute to the improvement of the prognosis of the diabetic foot in a management center.

\section{Keywords}

Diabetic Foot, Epidemiology, Therapeutics, Evolution, Mali Hospital

\section{Introduction}

According to the WHO, the number of people with diabetes worldwide has increased from 108 to 422 million over the past 30 years [1]. In Belgium, this number increased from around 300,000 to over 500,000 individuals between 2001 and 2011 [2]. Projections for 2030 are over one million [3]. In Africa, the number of diabetics was estimated at 14.2 million people in 2015 and 34.2 million are expected in 2040 [4].

The diabetic foot is defined according to the international consensus on the diabetic foot (developed by IWGDF: International Working Group on Diabetic Foot) of 2007 as any Infection, ulceration or destruction of the deep tissues of the foot associated with neuropathy and/or peripheral arterial disease of the lower limbs in diabetics [5].

These lesions in ill-balanced patients, difficult and expensive to treat most often lead to amputation, which makes this pathology a major public health problem, especially noting that every 30 seconds, a lower limb will be lost due to the diabetes [6].

Diabetic foot is a frequent and serious complication of diabetes with a very high rate of amputations of the lower limbs and often dramatic socio-economic and psychological consequences [7].

In Africa, foot injuries in diabetics are unfortunately very common. Poverty, poor hygiene and barefoot walking interact to aggravate the impact of foot injuries caused by diabetes [8]. In Mali there are few studies on diabetic foot [9] and there is an increase in the number of cases in the department. The objective of this study was to describe the epidemiological, therapeutic and evolutionary profile of the diabetic foot in a hospital setting in Mali.

\section{Methodology}

We conducted a retrospective, descriptive, cross-sectional study between September 1, 2011 and December 31, 2015 among diabetic patients aged 14 and over who arrived in the endocrinology/medicine department of the hospital in Mali.

Inclusion criteria:

- Study: retrospective, descriptive, transversal. 
- Duration: 4 years and 3 months.

- Be 14 years old and over.

- All diabetic patients who arrive in the endocrinology department of the hospital in Mali with a foot infection.

- We collected clinical, paraclinical and therapeutic data from these patients.

- Voluntary and informed consent was given in writing before being enrolled in the study.

Non-inclusion criteria:

We excluded from our series the incomplete files as well as the other causes apart from the diabetic foot.

Information was collected from patient charts using survey forms on which diabetic foot lesions were described according to the Texas classification (see Table 1). The questionnaires were entered and analyzed on Excel 2007 and SPSS version 20.0 software after data verification.

\section{Results}

We identified 94 cases of diabetic foot out of a total of 828 hospitalized patients, i.e. a prevalence of $11.35 \%$. The age range $41-60$ years represented (60.6\%), the extreme ages were 14 and 81 years (Cf. Table 2). Men 36 cases (38.3\%), women 57 cases $(60.6 \%)$ with a sex ratio of $0.62 \%$. Housewives 47 cases $50 \%$ (see Figure 1). Non-educated people 51 cases $(54.3 \%$ ) (see Figure 2 ). The economic standard of living was considered low in 40 cases (42.6\%) and sufficient in 54 (57.4\%). The presence of osteitis was observed in 40 cases (42.6\%). Doppler ultrasound was abnormal in 48 patients (51\%) (see Figure 3). Cytobacteriological examination of the pus was positive in 56 cases (59.6\%). Staphylococcus aureus was found in 21 samples $(22.4 \%)$ (see Table 3 ). The wounds were classified as stage D Grade 3 in 28 cases (29.8\%) (see Table 4). Fifty-nine (61.7\%) and $25.5 \%$ of the

Table 1. University of Texas classification (UT).

\begin{tabular}{ccccc}
\hline & $\begin{array}{c}\text { Grade 0 } \\
\text { Lesion } \\
\text { epithelialized }\end{array}$ & $\begin{array}{c}\text { Grade 1 } \\
\text { Wound } \\
\text { superficial }\end{array}$ & $\begin{array}{c}\text { Grade 2 } \\
\text { Tendon } \\
\text { involvement }\end{array}$ & $\begin{array}{c}\text { Grade 3 } \\
\text { Damage to the } \\
\text { bone or joint }\end{array}$ \\
\hline $\begin{array}{c}\text { Stage A } \\
\text { No infection } \\
\text { No ischemia }\end{array}$ & 0A & $1 \mathrm{~A}$ & $2 \mathrm{~A}$ & $3 \mathrm{~A}$ \\
\hline $\begin{array}{c}\text { Stage B } \\
\text { Infection, but } \\
\text { No ischemia }\end{array}$ & 0B & $1 \mathrm{AB}$ & $2 \mathrm{~B}$ & $3 \mathrm{~B}$ \\
\hline $\begin{array}{c}\text { Stage C } \\
\text { No infection } \\
\text { But ischemia }\end{array}$ & 0C & $1 \mathrm{C}$ & $2 \mathrm{C}$ & $3 \mathrm{C}$ \\
\hline $\begin{array}{c}\text { Stage D } \\
\text { Infection and ischemia }\end{array}$ & 0D & $1 \mathrm{D}$ & $2 \mathrm{D}$ & $3 \mathrm{D}$ \\
\hline
\end{tabular}


Table 2. Age distribution of patients.

\begin{tabular}{ccc}
\hline AGE (year) & Workforce & Percentage \\
\hline $14-20$ & 1 & 1.06 \\
$21-40$ & 7 & 7.98 \\
$41-60$ & 57 & 60.6 \\
$61-81$ & 28 & 29.79 \\
Total & 94 & 100 \\
\hline
\end{tabular}

Table 3. Distribution according to the germs found in the culture.

\begin{tabular}{ccc}
\hline Isolated germs & Workforce & Percentage \\
\hline Staphylococcus aureus & 21 & 22.34 \\
Klebseilla Pneumonieux & 9 & 9.57 \\
E. coli & 11 & 11.70 \\
Morganela morga & 6 & 6.38 \\
Protus mirabilis & 5 & 5.31 \\
Pseudomonas aeruginosa & 4 & 4.25 \\
Sterile & 37 & 39.36 \\
Not done & 1 & 1.06 \\
Total & 94 & 100
\end{tabular}

Table 4. Distribution of patients by Texas classification.

\begin{tabular}{ccccc}
\hline \multirow{2}{*}{ Grade } & \multicolumn{4}{c}{ Wound stage } \\
\cline { 2 - 5 } & Stage A & Stage B & Stage C & Stage D \\
\hline Grade 0 & 5 & 2 & 0 & 0 \\
Grade 1 & 8 & 19 & 0 & 0 \\
Grade 2 & 0 & 16 & 5 & 4 \\
Grade 3 & 0 & 4 & 3 & 28 \\
Total & 13 & 41 & 8 & 32 \\
\hline
\end{tabular}

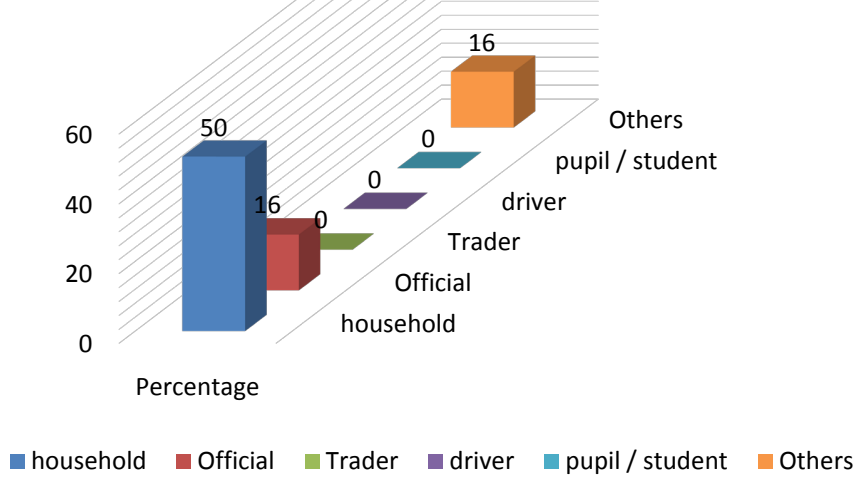

Figure 1. Distribution of patients by occupation. 


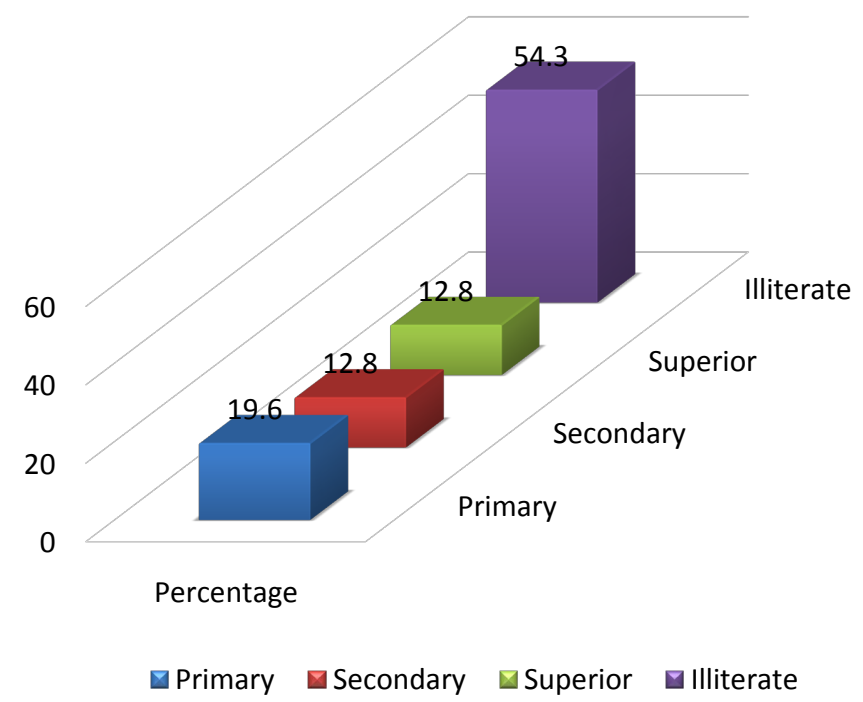

Figure 2. Distribution of patients by education level.

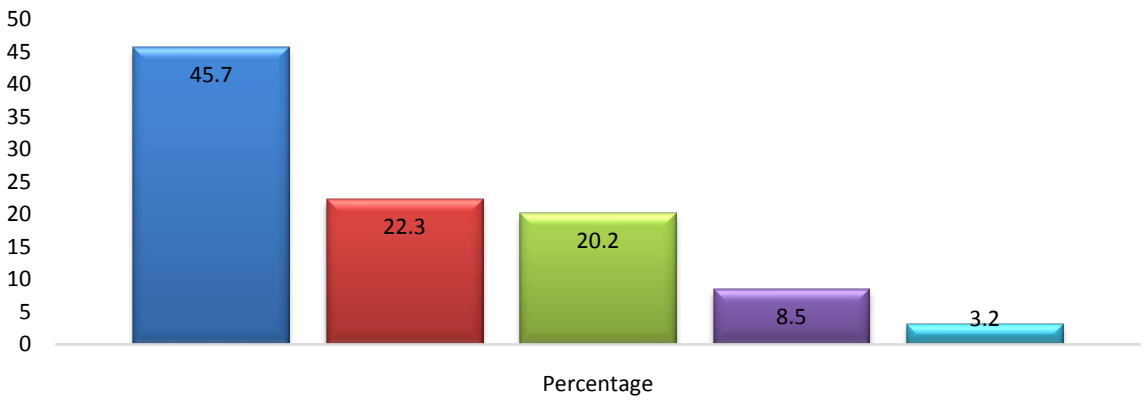

$\square$ Normal $\square$ Stenosing arterial disease $\square$ Non-stenosing arterial disease $\square$ Vein thrombosis $\square$ Not done

Figure 3. Distribution of patients by Doppler ultrasound findings.

patients were on insulin and oral anti-diabetic drugs respectively, while $12.8 \%$ had no anti-diabetic treatment. Medical treatment was mainly Amoxicillin + Metronidazole used in 36 cases (38.29\%) and amputation was performed in 35 cases (37.2\%) (Cf. Table 5, Table 6). The evolution was favorable in 85 cases (90.4\%), 9.6\% (5 patients) died of which the main causes were hypoglycemia in 4 cases and sepsis in 3 cases.

\section{Discussion}

The study included 94 cases out of a total of 828 hospitalized patients, for a prevalence of $11.35 \%$. This hospital prevalence is close to those reported by Djim. F et al. [9] and Koffi D [10] respectively $16.37 \%$ and $15.29 \%$. In Africa, it is estimated overall at 5.5\% [11] and in France (ENTRED), the prevalence is 6\% [12].

The 41 - 60 age group was the most represented, 60.6\%, Djim. F et al. [9] found 59.6\%. The average age was 42.66 years, other African studies: SANI.R et al. [13], Nghario L et al. [14], Gueye D.D et al. [15], Dr Merad M S et al. [16], Mohaman Djibril et al. [17] found respectively 53 years, 54 years, 57 years, 60.5 years, 60.74 years. That reported in European literature varies between 67 years 
Table 5. Distribution of patients according to the type of antibiotics used.

\begin{tabular}{ccc}
\hline Antibiotics & Workforce & Percentage \\
\hline Ciprofloxacin + Metronidazole & 36 & 38.29 \\
Amoxicillin + acid Clavilanique + Gentamicine & 19 & 20.21 \\
Ceftriaxone + Gentamicine & 14 & 14.89 \\
Fusidic acid & 11 & 11.70 \\
Cefotaxime & 6 & 6.38 \\
Imipenème & 8 & 8.51 \\
Total & 94 & 100 \\
\hline
\end{tabular}

Table 6. Distribution of patients according to surgical management.

\begin{tabular}{ccc}
\hline Therapeutic gestures & Workforce & Percentage \\
\hline Disarticulation of the toes & 9 & 9.6 \\
Transmetatarsal amputation & 4 & 4.3 \\
Trans-femoral amputation & 2 & 2.1 \\
Amputation of the lower 1/3 of the leg & 9 & 9.6 \\
Amputation of the middle 1/3 of the leg & 5 & 5.3 \\
Amputation of the upper 1/3 of the leg & 6 & 6.4 \\
Revascularization & 1 & 1.1 \\
Disarticulation of the knee & 1 & 1.1 \\
Not applicable & 57 & 60.6 \\
Total & 94 & 100 \\
\hline
\end{tabular}

and 73 years [18]. This age difference can be explained by the young age of onset of diabetes in African populations, but above all by poor treatment compliance by our patients. The reasons for this poor compliance are multiple: the non-acceptance of diabetes, traditional therapy, beliefs and especially poverty [19].

Women were in the majority (61.7\%) against $38.3 \%$ for men with a sex ratio of $0.62 \%$. This female predominance has been noted by some authors such as Samaké D [20]. On the other hand, the male predominance which has been studied by Dr Merad M S et al. [16] (sex ratio M/F 2.33) is a phenomenon confirmed by several authors. Sani et al. [13] found a sex ratio of 2.46; it is 2.5 for Amoussou-Guenou [21]. The generally recognized poor adherence to therapy in men explained this male predominance [22].

Housewives were the most represented in our study (50\%). This same predominance was observed by Djim F et al. [9] 53.3\%.

The majority of our patients were not educated with $54.3 \%$. This same result was observed by Traoré D.Y [23] 55.5\% and Nghario L et al. [14] 47\%. In fact, ignorance of the diabetic status due to illiteracy has also been reported in a variable proportion in the African literature: $13.1 \%$ in Niger [24]; 27.9\% in Tanzania [25]. 
The socio-economic level was low in 42.6\%, Nghario L et al. [14] found a low level in $66.10 \%$ of patients. The Doppler ultrasound was abnormal in $51 \%$ of our patients. Djim F C. et al. [9] had $48.6 \%$ arteriopathy of the lower limbs and $20 \%$ obliteration.

The presence of germs was noted in $59.6 \%$ of samples taken from wounds. Nghario L et al. [14] had reported in $50 \%$ of his samples.

Among the germs isolated, staphylococcus aureus was found more in $22.4 \%$, the same germ was the most isolated in $16.13 \%$ in Djim F C. et al. [9]. On the other hand, in the Aouam study [26], the most frequently found germ was Pseudomonas aeruginosa. A study done in India and published in 2017 found poly-microbial infections in $54 \%$ with other mono-microbial in $43 \%$. [27]. In Morocco the bacteriological sample carried out had objectified the multisensitive Staphylococcus aureus in $28.23 \%$ [28].

According to the University of Texas classification, the foot was classified as stage D Grade 3 in (29.8\%), Guèye D.D et al. [15] found grade 1b lesions which represented $34.0 \%$, followed by $26.4 \%$ by grade $2 \mathrm{~d}$ lesions and $24.5 \%$ by grade $3 \mathrm{~d}$ lesions. Also, Dr Merad M S et al. [16], had found osteitis at Stage 3D in 46\% of patients.

During hospitalization, insulin therapy alone was started in $61.7 \%$ of cases. This result was with Djim F et al. [9] in Mali with 95.7\% insulin therapy and Dr L. Elazizi et al. [29] had performed insulin therapy in $77.20 \%$ of patients. The most widely used antibiotic therapy was the combination Ciprofloxacin $+\mathrm{Me}-$ tronidazole in $38.29 \%$ of cases, the same combination found in Djim F et al. [9] at $37.8 \%$. Similarly, this antibiotic therapy was generally introduced by Dr L. Elazizi et al. [29] in $89.20 \%$.

Amputation was performed in $37.2 \%$ of our patients including $24.3 \%$ in the lower $1 / 3$ of the leg, $16.3 \%$ in the upper $1 / 3$ of the leg and a disarticulation of the big toe in $24,3 \%$ of cases. SANI.R et al. [13] found amputation in 37 cases (41.1\%), of which the amputation site was the foot in 23 cases $(62.2 \%)$ followed by the leg in 11 cases $(29,7 \%)$ and the thigh in 3 cases. Case $(8.1 \%)$, as well as authors such as Sidibé AT et al. [30] and Merad M S et al. [16] reported respectively $41.36 \%$ and $34 \%$ of amputations in their studies.

The outcome was favorable in $90.4 \%$ of cases, other favorable results have been reported by authors such as Koffi D [10] which reported $91.70 \%$ and $71 \%$ of cases in Assia EL Ouarradi [31].

We recorded a mortality rate of $9.6 \%$ during the study period. This rate was reported at Djim. F et al. [9], Sidibé AT et al. [30], Gueye D.D et al. [15], SANI.R et al. [13], Djibril et al. [17] respectively 10.6\%; 5.75\%; 16.9\%; 16.7\%; 6.45\%. Hypoglycemia in $4.3 \%$ of cases was the leading cause of death. Djim. F et al. [9] found that sepsis was the cause of death (60\%) and for Nghario L et al. [14] sepsis and hyperglycemia were the main causes of death in $50 \%$ of cases.

\section{Conclusion}

Foot lesions are relatively frequent in our diabetic patients, and are responsible 
for high mortality and morbidity. A delay in management with lesions received at advanced stages is always noted. The management of the diabetic foot must be multidisciplinary.

\section{Conflicts of Interest}

The authors declare no conflicts of interest regarding the publication of this paper.

\section{References}

[1] OMS (Organisation mondiale de la santé) (2016) Rapport mondial sur le diabète. Organisation mondiale de la santé, Geneva.

[2] OMS (Organisation mondiale de la santé) (2016) Rapport Belgique sur le diabète. Organisation mondiale de la santé, Geneva

[3] Alliance Nationale des Mutualités Chrétiennes (2012) Rapport sur l'épidémiologie du diabète.

[4] International Diabetes Federation (2015) Diabetes Atlas. 7th Edition. International Diabetes Federation, Brussels.

[5] International Working Group in the Diabetic Foot (2007) International Consensus on the Diabetic Foot Ant Practical Guidelines on the Management and Prevention oh the Diabetic Foot. Journal of Medical Rehabilitation: Practice and Training in Physical Medicine and Rehabilitation, 31, 14-21.

[6] El Hariri, L.R. (2005) Communiqué de presse de la Fédération Mondiale du diabète Diabète: Évitons l'amputation. Doctissimo, Articles 9039. http://www.doctissimo.fr/dossierdiabète

[7] Dia, A.M., Affangla, A.D., Dione, J.M., Akpo, G., Mbengue, M., Ka, M.M., et al. (2015) Apport de l'écho-doppler artériel des membres inférieurs dans la prise en charge du pied diabétique à l'hôpital Saint-Jean de Dieu de Thiès (Sénégal). Pan African Medical Journal, 22, Article No. 193. https://doi.org/10.11604/pamj.2015.22.193.5992

[8] Monabeka, H.G. and Nsakala-Kibangou, N. (2001) Aspects épidémiologiques et cliniques du pied diabétique au CHU de Brazzaville. Bulletin de la Société de Pathologie Exotique, 94, 246-248.

[9] Djim, F.C. (2014) Fréquence et prise en charge des pieds diabétiques dans le service de médecine et d'endocrinologie de l'hôpital du Mali Med. FMOS, Bamako.

[10] Koffi, D.P. (2013) Pied diabétique dans le service d'endocrinologie -diabétologie du CHU de Yopougon, février2013, Yopougon; Colloque SERVIER-2013. [En ligne].

[11] Zhang, P., Lu, J., Jing, Y., Tang, S., Zhu, D. and Bi, Y. (2017) Global Epidemiology of Diabetic Foot Ulceration: A Systematic Review and Meta-Analysis. Annals of Medicine, 49, 106-116. https://doi.org/10.1080/07853890.2016.1231932

[12] Richard, J.L. and Schuldiner, S. (2008) Epidémiologie du pied diabétique. La Revue de Médecine Interne, 29, S222-S230. https://doi.org/10.1016/S0248-8663(08)73949-3

[13] sani, R., et al. (2010) Le pied diabétique: Aspects épidémiologiques, cliniques et thérapeutiques à l'hôpital national de Niamey A propos de 90 cas. Medecine D'Afrique Noire, 57, 172-176.

[14] Nghario, L., et al. (2017) Les pieds diabétiques: Aspects épidémiologique, clinique et thérapeutique à propos de 62 cas. Revue de chirurgie d Afrique centrale (recac), 2, 
9-24.

[15] Guèye, D.D., et al. (2020) Profil épidémio-clinique et évolutif du pied diabétique au Centre Hospitalier Régional de Saint-Louis. Revue Africaine de Médecine Interne, 7, 14-18.

[16] Merad, M.S., et al. (2019) Les infections du pied diabétique à la Clinique Larribère. Congres de la societe Algerienne de diabetologie (SADIAB), Alger, 14-16 novembre 2019, 12 .

[17] Djibril, M., et al. (2018) Pied diabétique: Aspects épidémiologique, diagnostique, thérapeutique et évolutif à la Clinique Médico-chirurgicale du CHU Sylvanus Olympio de Lomé. The Pan African Medical Journal, 30, Article No. 4. https://doi.org/10.11604/pamj.2018.30.4.14765

[18] Carpentier, B., Pradines, S., Benhamou, P.Y. and Halimi, S. (2000) Health Costs Associated with the Diabetic Foot in Developed Countries: A Plea for the Creation of Healthcare Networks. Diabetes $M$ tab., 26, 75-80.

[19] Goeh-akue, E., Pio, M., Afassinou, Y., Baragou, S., Mossi, K.E., Pessinaba, S., et al. (2015) Apport de l'écho doppler vasculaire dans le diagnostic lésionnel du pied diabétique ouvert chez le diabétique de type 2 à Lomé. Angéiologie, 67, 1-7.

[20] Samaké, D. (2005) Etude épidémioclinique les amputations consécutives aux complications du diabète dans le service de chirurgie orthopédique et traumatologique de l'Hôpital Gabriel Toure. Thèse: Med, FMOS, Bamako, N = 05M155.

[21] Amoussou-Guenou, D., Wanvoegbe, F.A., Boko, E., Segnon-agueh, J., Agbodande, K.A., Kerekou, A., et al. (2015) Aspects bactériologiques des plaies et leur prise en charge chez les diabétiques à Cotonou: Étude prospective à propos de 42 cas. Médecine d Afrique Noire, 62, 241-246.

[22] Bidingua, M., Kayembe, K. and Ditu, M. (2004) Profil clinique du pied diabétique: À propos de 63 cas suivis à la Clinique Universitaire de Kinshasa. Congo Médical, 3, 1304-1311.

[23] Traoré, D.Y. (2013) La prévalence de la neuropathie diabétique en commune I du district de Bamako. Thèse: Med, FMOS, Bamako, $\mathrm{N}=13 \mathrm{M} 203$.

[24] Edo, A.E., Edo, G.O. and Ezeani, I.U. (2013) Risk Factors Ulcer Grade and Management Outcome of Diabetic Foot Ulcers in a Tropical Tertiary Care Hospital. Nigerian Journal of Medicine, 54, 59-63. https://doi.org/10.4103/0300-1652.108900

[25] Chalya, P.L., Mabula, J.B., Dass, R.M., et al. (2011) Surgical Management of Diabetic Foot Ulcers: A Tanzania University Teaching Hospital Experience. BMC Research Notes, 4, Article No. 365. https://doi.org/10.1186/1756-0500-4-365

[26] Aouam, A., Sayadi, H., Sallem, O., Kechida, M. and Khochtali, I. (2018) Prise en charge des pieds diabétiques infectés: À propos de 54 cas. Annales d'Endocrinologie, 79, 462. https://doi.org/10.1016/j.ando.2018.06.984

[27] Saseedharan, S., Sahu, M., Chaddha, R., Pathrose, E., Bal, A., Bhalekar, P., Sekar, P. and Krishnan, P. (2018) Epidemiology of Diabetic Foot Infections in a Reference Tertiary Hospital in India. Brazilian Journal of Microbiology, 49, 401-406. https://doi.org/10.1016/j.bjm.2017.09.003

[28] Laidi, S., El Aziz, S. and Chadli, A. (2016) Prise en charge du pied diabétique infecté au CHU Ibn Rochd de Casablanca: À propos de 244 cas. Annales d Endocrinologie, 77, 498-528. https://doi.org/10.1016/j.ando.2016.07.805

[29] Elazizi, L., Lazar, N., Mohib, A., et al. (2021) Pied diabétique: Aspects épidémiologique, diagnostique, thérapeutique et évolutif. Annales d Endocrinologie, 82, 492. https://doi.org/10.1016/j.ando.2021.08.698 
[30] Sidibé, A.T., et al. (2006) Pied diabétique en médecine interne de l'hôpital du Point "G". La Revue de Médecine Interne, 8, 14-17.

[31] Ouarradi, A.E.L. (2019) Pied diabétique: Profil épidémiologique thérapeutique et pronostique. Thèse No. 106, Faculté de médecine et de Pharmacie, Marrakech. 